\title{
INFORMACIÓN PARA LOS AUTORES
}

\author{
Normas para el envío de originales
}

1. Temas de interés. La Revista de Historia Económica. Journal of Iberian and Latin American Economic History publica artículos de investigación sobre historia económica, historia del pensamiento económico y todos aquellos campos de la economía relacionados con el análisis del largo plazo. El ámbito geográfico de sus artículos lo constituyen, preferentemente, la Península Ibérica e Iberoamérica, así como aquellas áreas, más amplias, que engloban a las anteriores. Los trabajos que se envíen a la Revista han de ser originales, no publicados ni sometidos a consideración para su publicación en otra parte.

Esta Revista está incluida en ECON-LIT, CABELL'S, HA, LATIN INDEX, IBSS y CINDOC-ISOC.

2. Tiempos de publicación y proceso de evaluación. RHE-JILAEH publica tres números al año (primavera, otoño, invierno), por tanto el n. ${ }^{\circ} 1$, el n. ${ }^{\circ} 2$ y el n..$^{\circ} 3$ salen publicados con anterioridad al 21 de marzo, 21 de septiembre, 21 de diciembre, de cada año respectivamente. Los editores se proponen ser rigurosos y transparentes en el proceso de revisión haciendo explícito el protocolo de evaluación desde el acuse de recibo hasta la aceptación final (ver Proceso de Revisión); así como razonablemente expeditivos entre la aceptación del manuscrito y su publicación.

3. Envío. Los originales se enviarán en español, inglés o portugués, escritos en Microsoft Word. Se enviarán preferentemente por correo electrónico a la dirección rhejilaeh@uc3m.es; excepcionalmente, se podrán enviar también en papel (una copia), junto con un archivo en disquete o CD ROM, a nombre del Director responsable de la Revista y a las señas siguientes:

Prof. Antonio Tena (antonio.tena@uc3m.es).

Departamento de Historia Económica.

Universidad Carlos III de Madrid.

C/ Madrid, 126.

E-28903 Getafe (España).

RHE-JILAEH acusará recibo de todos los originales en un plazo no superior a diez días desde su recepción.

4. Formato. Los originales deberán ir escritos a doble espacio, en letra Times New Roman tamaño 12. La extensión total no superará las 30 páginas (10.000 a 12.000 palabras), incluidos gráficos, cuadros, notas a pie de página, bibliografía y apéndices en su caso. La primera página incluirá el título, nombre del autor o autores, filiación académica, dirección tanto de correo ordinario como de correo electrónico, y número(s) de teléfono. En una segunda página se presentarán dos resúmenes, en español (portugués) e inglés, de unas 120 palabras cada uno, entre tres y cinco palabras clave (en los dos idiomas) y la(s) clasificación(es) JEL. Con el fin de garantizar el anonimato en el proceso de evaluación, el resto del texto no podrá incluir ninguna mención al autor o autores (incluidas las que se hagan en notas a pie de página) que permita desvelar su identidad. Los originales observarán el siguiente orden: texto con sus notas a pie de página, seguido por apéndices y bibliografía. En la medida de lo posible, los cuadros, gráficos y mapas se insertarán en sus lugares dentro del texto, con el mismo tipo de letra que éste y a tamaño similar; cuando no, deberán ir incluidos al final del texto, o en un archivo separado. Todas las páginas habrán de ir numeradas correlativamente. La notas, debates y ensayos bibliográficos no deberán superar las 10 páginas (3.3004.000 palabras).

\section{Normas de edición:}

a. Bibliografía. Las referencias bibliográficas irán ordenadas alfabéticamente por el apellido (en mayúsculas) del autor, bajo el título «Bibliografía» y al final del original. Si se citan dos o más obras de un determinado autor publicadas en el mismo año, éstas se distinguirán por medio de una letra. Ejemplo: Clark (2004a) y Clark (2004b). Las referencias se limitarán a obras citadas en el trabajo. Como ejemplos, se incluyen los siguientes: 
MARTÍN ACEÑA, P., y PONS, M. ${ }^{a}$ A. (2005): «El sistema monetario y financiero», en A. Carreras y X. Tafunell (coords.), Estadísticas históricas de España: siglos XIX y XX. Bilbao: Fundación BBVA, pp. 645-706.

FOGEL, Robert W. (1994): «Economic Growth, Population Theory, and Physiology: The Bearing of Long-Term Processes on the Making of Economic Policy». American Economic Review 84 (3), pp. 369-395.

HABER, S.; MAURER, N., y RAZO, A. (2003): The Politics of Properties Rights: Political Instability, Credible Commitments, and Economic Growth in Mexico, 1876-1929. Londres: Cambridge University Press.

Si el artículo incluye referencias a fuentes de archivo, éstas se relacionarán aparte y antes de la Bibliografía, bajo el título de «Fuentes».

b. Notas a pie de página. Todas las notas irán a pie de página, numeradas mediante caracteres arábigos, en formato superíndice y en orden creciente, siempre antes de un punto. En las notas no se incluirán las referencias bibliográficas completas, sino solamente su forma abreviada. Ejemplo: Cubel (2003: 322-325).

c. Citas. Las citas irán entrecomilladas y, cuando excedan de tres líneas, separadas del cuerpo principal del texto. En este último caso, irán sangradas y a espacio sencillo. Cualquier cambio introducido en la cita original deberá indicarse encerrándolo entre corchetes.

d. Figuras. Los cuadros, gráficos y mapas habrán de ser originales; llevarán un encabezamiento breve, irán numerados por orden de aparición en el texto, y especificarán la fuente de la que proceden.

6. Adecuación de los artículos aceptados a las normas de edición. Los autores de los artículos aceptados, en cualquier caso, deberán enviar una nueva versión adaptada al formulario de «normas de edición RHE-JILAEH» en un plazo nunca superior a los diez días.

7. Corrección de pruebas. Los autores de artículos aceptados para publicación podrán ser requeridos para la corrección de pruebas de imprenta, que habrán de ser devueltas en un plazo siempre inferior a los diez días. No se permitirá la introducción de cambios sustanciales en las pruebas, quedando éstos limitados a la corrección de errores con respecto a la versión aceptada.

8. Copyright. Es condición para la publicación que el autor o autores ceda(n) a la Revista de Historia Económica los derechos de reproducción. Si se producen peticiones de terceros para reproducir o traducir artículos o partes de los mismos, la decisión corresponderá al Consejo Editorial.

9. Aviso. Cualquier incumplimiento de las presentes Instrucciones constituirá motivo para el rechazo del original remitido y, como mínimo, será causa de retraso en su proceso. 


\section{SUBMISSION INFORMATION}

1. Topics of interest. The Revista de Historia Económica. Journal of Iberian and Latin American Economic History publishes original research papers on economic history, economic thought and all those areas of economics concerned with long-term analysis. The geographical area addressed in these papers should preferably cover Spanish and Portuguese speaking countries and wider areas including any of these countries. Papers should be original and should be neither published nor be under consideration for publication elsewhere.

This Journal is included in ECON-LIT, LATIN INDEX, CABELL'S, HA, IBSS and CINDOC-ISOC.

2. Publication times and review process. RHE-JILAEH publishes three issues yearly (spring, autumn and winter) with Numbers 1, 2 and 3 being published before March $21^{\text {st }}$, September $21^{\text {st }}$ and December $21^{\text {st }}$ respectively each year. The editors will make every attempt to be rigorous and transparent throughout the evaluation process from the initial receipt of the manuscript to its final acceptance (see Review Process); we also make a commitment to reduce the time between acceptance of an article and its publication as far as possible.

3. Submission of manuscripts. The manuscripts may be sent in Spanish, English or Portuguese and should preferably be sent by e-mail (rhe-jilaeh@uc3m.es) or, if not, a paper copy (one) together with a Microsoft Word or PDF file on a disk or CD-ROM to the address given below. The graphs, tables and maps which can not be included in the file may be submitted in an additional Microsoft Excel file. The mailing address for submission of manuscripts is:

Prof. Antonio Tena (antonio.tena@uc3m.es).

Departamento de Historia Económica.

Universidad Carlos III de Madrid.

C/ Madrid, 126.

E-28903 Getafe (España).

RHE-JILAEH will acknowledge receipt of all manuscripts within 10 days of reception.

4. Format of submission. Manuscripts are to be submitted in double-spaced Times New Roman point 12 format. The text length should not exceed 30 pages $(10,000$ to 12,000 words), including graphs, tables, footnotes and references. The first page of the paper should include the title, name of author(s), affiliation, full address, e-mail and telephone number. Abstracts in Spanish and English of about 120 words, three to five keywords and JEL classification should be included on a second page. The rest of the manuscript must not include further references to the author(s) or any other mention which may reveal their identity (including references made in footnotes) in order to ensure the anonymous double-blind refereeing process. The structure of papers should be: text with footnotes, followed by appendices, and references (the latter single-spaced). When possible, graphs, tables and maps should be included on the corresponding text page, using the same font and a similar letter size as used in the text. If this is not possible, they may be included at the end of the manuscript or in a separate file. All pages should be numbered. Notes, Surveys and Speculations, Comments and Review of periodical literature should not be more than 10 pages $(3,300-4,000$ words $)$ in length.

\section{Editing guidelianes:}

a. References. Bibliographical references should be listed by surname of author (in capital letters) in alphabetical order under a separate heading at the end of the manuscript. If more than one text by the same author(s) is cited for a particular year, then the works should be distinguished by a letter, e.g. Clark (2004a) and Clark (2004b). References are limited to the works cited in the manuscript. The following examples show the format to be applied to references:

MARTÍN ACEÑA, P., y PONS, M. ${ }^{\text {a }}$ A. (2005): «El sistema monetario y financiero», in A. Carreras and X. Tafunell (coords.), Estadísticas históricas de España: siglos XIX y XX. Bilbao: Fundación BBVA, pp. 645-706. 
FOGEL, Robert W. (1994): «Economic Growth, Population Theory and Physiology: The Bearing of Long-Term Processes on the Making of Economic Policy». American Economic Review 84 (3), pp. 369-395.

HABER, S.; MAURER, N., y RAZO, A. (2003): The Politics of Property Rights: Political Instability, Credible Commitments, and Economic Growth in Mexico, 1876-1929. London: Cambridge University Press.

If the paper includes references to archives, statistics or documentary sources, these should be listed under an additional 'Sources' heading.

b. Footnotes. All notes are to be included as footnotes and numbered in ascending order of appearance in Arabic numbers as superscript before the full stop at the end of the sentence. Complete bibliographical references should not be included in the notes but rather in an abbreviated form, i.e. Cubel (2003: 322-325).

c. Quotations. Literal quotations should be limited and separated from the rest of the text if they exceed three lines. In this case they will be single-spaced and indented. All other quotations may appear in the text and should be clearly identified by quotation marks. Any change(s) made to the original quotation will be indicated by square brackets.

d. Figures. Tables, graphs, and maps should be original. They will include a short title, should be numbered in order of appearance and include the corresponding sources.

6. Upon acceptance of an article. Authors will be asked to resubmit a new version applying the more detailed RHE-JILAEH publication norms.

7. Galley proofs. Once the manuscript has been finally accepted for publication, the author(s) may receive galley proofs which are to be returned within 72 hours. Substantial changes to these proofs are not allowed and changes should be limited to lay-out corrections of the accepted manuscript.

8. Copyright. It is a condition of publication that the author(s) assign(s) copyright of their articles to the Revista de Historia Económica. Journal of Iberian and Latin American Economic History. Requests from third parties to reproduce or translate parts or the whole of articles will be considered by the editorial board.

9. Caveat. Any failure to comply with these guidelines may be considered a reason for rejection of the manuscript submitted or occasion a substantial delay in its processing. 


\section{PROCESO DE REVISIÓN \\ Protocolo de evaluación, revisión de originales y notas de investigación}

RHE- JILAEH, preocupado por la necesidad de acortar los tiempos y mejorar la transparencia del proceso de evaluación de los artículos, cree necesario que los autores y evaluadores sean conscientes del protocolo de evaluación y revisión desde la llegada del original hasta la aceptación final del artículo.

Acuse de recibo

RHE-JILAEH se compromete a hacer acuse de recibo del manuscrito original al autor en un plazo inferior a diez días si éste es recibido por medios telemáticos.

\section{Evaluación Inicial}

Todos los originales publicados en esta revista serán sometidos al proceso de doble evaluación anónima externa por pares salvo indicación explícita de lo contrario. Previamente, los manuscritos recibidos pasarán por una "pronta revisión» por los editores u otros especialistas del área, usualmente del Comité Editorial, en la que se preserva el anonimato del autor. Esta revisión consiste en discernir su originalidad, relevancia e interés científico, para decidir su paso o no a revisión externa, lo que será notificado a los autores en un plazo inferior a treinta días a partir del acuse de recibo del manuscrito.

\section{Evaluación completa}

Si la revisión inicial es positiva, RHE-JILAEH mandará el manuscrito a dos o más especialistas externos, siguiendo el sistema de revisión por pares con el formato doblemente ciego, lo que no implica compromiso ninguno de aceptación. Sólo después de haber recibido por lo menos dos de los informes pedidos, RHE-JILAEH tomará una decisión sobre el manuscrito. RHE- JILAEH urge a los especialistas a revisar los manuscritos con celeridad (entre tres y cinco semanas), esto permitirá contar con una decisión final en menos de tres meses desde la comunicación a los autores del envío a revisión completa del manuscrito.

En todos los siguientes casos, después de la Evaluación completa del manuscrito, los autores recibirán los comentarios de forma anónima elaborados por los especialistas.

\section{Aceptación y aceptación condicional}

Si las revisiones de los especialistas anónimos son favorables, el manuscrito será usualmente aceptado, condicionado a que el autor considere los comentarios y dudas propuestos en las revisiones. Sólo muy ocasionalmente un manuscrito es aceptado sin requerir al menos ciertas revisiones mínimas.

\section{Revisar y reenviar}

Si las revisiones de los especialistas anónimos son en su mayoría favorables, pero al mismo tiempo varias revisiones y cambios son sugeridos, el manuscrito será rechazado con la sugerencia de que el autor considere los comentarios y reenvíe el manuscrito revisado. Si el autor realiza los cambios y reenvía el manuscrito a RHE - JILAEH, éste será enviado a uno de los especialistas anónimos originales y a un nuevo experto en la materia. En esta revisión, los especialistas evaluarán los comentarios y cambios realizados por el autor después de haber introducido las críticas originales. En este caso, el proceso de revisión también es realizado de forma anónima. Si las revisiones del manuscrito reenviado son favorables, es probable que el manuscrito sea aceptado para publicación.

\section{Adecuación de los artículos aceptados a las normas de edición}

Los autores de los artículos aceptados, en cualquier caso, deberán enviar una nueva versión adaptada al formulario de «normas de edición RHE-JILAEH» en un plazo nunca superior a los diez días.

\section{Corrección de pruebas de artículos aceptados para publicación}

Los autores podrán ser requeridos para la corrección de pruebas de imprenta, que habrán de ser devueltas en un plazo inferior a las 72 horas. No se permitirá la introducción de cambios sustanciales en las pruebas, quedando éstos limitados a la corrección de errores con respecto a la versión aceptada.

Nota importante: Todo artículo que no haya sido reelaborado y entregado antes de los seis meses desde la recepción de los informes de los especialistas deberá iniciar el proceso de revisión. 


\section{REVIEW PROCESS \\ Evaluation and review process for original documents and research notes}

In the interests of making the evaluation process for articles more transparent and more streamlined, RHE-JILAEH provides the following information for authors and evaluators regarding the evaluation and revision process from the arrival of the original through to publication of the article.

\section{Acknowledgment of receipt}

RHE-JILAEH promises to acknowledge receipt of an original manuscript within 10 days when the manuscript is received in electronic format.

\section{Initial Evaluation}

Every manuscript published in this review will be subjected of an external double blind peer review process unless explicit indication to the contrary is made. Manuscripts will be subjected to a «rapid review» by the editors or other specialists in the particular area who will usually be members of the Editorial Board. This review will focus on originality, relevance and scientific interest in order to decide whether the text is submitted to an external review. This decision will be communicated to authors within a maximum of 30 days from the acknowledgment of receipt of the manuscript.

\section{Full Evaluation}

If the initial evaluation is positive, RHE-JILAEH will send the manuscript to two or more external experts, following the peer review system, with the double-blind format. This does not imply that the article will be accepted. RHE-JILAEH will only take a decision after receiving at least two of the referees' reports. RHE-JILAEH encourages specialists to review manuscripts quickly (within a period of three to five weeks) to allow a final decision within three months of the decision to send a manuscript for full review.

In all the following cases authors will receive, on completion of the evaluation process, the anonymous comments made by the specialists.

\section{Acceptance and Conditional Acceptance}

If the reviews made by the anonymous specialists are favourable, the manuscript will usually be accepted on the condition that the author considers the comments and doubts expressed in the reviews. It is rare for an article to be accepted which requires absolutely no changes at all.

\section{Revise and resubmit}

If the majority of the above reviews is favourable but suggests revision and changes in the manuscript, the text will be rejected and the author will be invited to consider the specialists' comments and resubmit a revised document. If the author incorporates the suggested changes and resubmits the manuscript it will be sent to one of the original anonymous referees and to a new expert in the field. At this stage the specialists will evaluate the author's comments and the changes made as a result of the original criticisms. This review process is also anonymous. If the reviews of the resubmitted manuscript are favourable it is likely that the text will be accepted for publication.

\section{Adaptation of accepted articles to the publication norms}

Authors of accepted articles will be required to send a new version of the manuscript in which the RHE-JILAEH publication norms are applied within a maximum of 10 days.

\section{Correction of proofs of articles accepted for publication}

Authors may be required to correct galley proofs which should be returned within 72 hours. Major changes are not permitted at this stage, the objective being simply to correct errors with respect to the accepted version.

Note: An article no resubmitted within six month from the referees' report will be considered a new submission. 
vol. XI $n^{\circ} 1$

jan.jun. 2008

\section{Támas Szmrecsányi}

5 Contribuições de Edith Penrose (1914-1996) à historiografia das empresas multinacionais

Carlos Alberto Cordovano Vieira

29 Interpretações da colônia: leitura das contribuições de Nelson Werneck Sodré e Alberto Passos Guimarães

Graciela de Souza Oliver

63 Análise comparativa das políticas de combate ao mosaico da cana-de-açúcar em São Paulo e em Minas Gerais

\section{Luís Augusto Farinatti}

91 Os grandes estancieiros e além: criadores de gado na fronteira meridional do Brasil (Alegrete, 1831-1970)

Paulo Roberto Cimó Queiroz

119 O desafio do espaço platino às tendências de integração do antigo sul de Mato Grosso ao mercado nacional brasileiro: um hiato em dois tempos

155 Resenha bibliográfica do livro A Farewell to Alms - a brief economic history of the world de Gregory Clark, por Mauricio C. Coutinho 

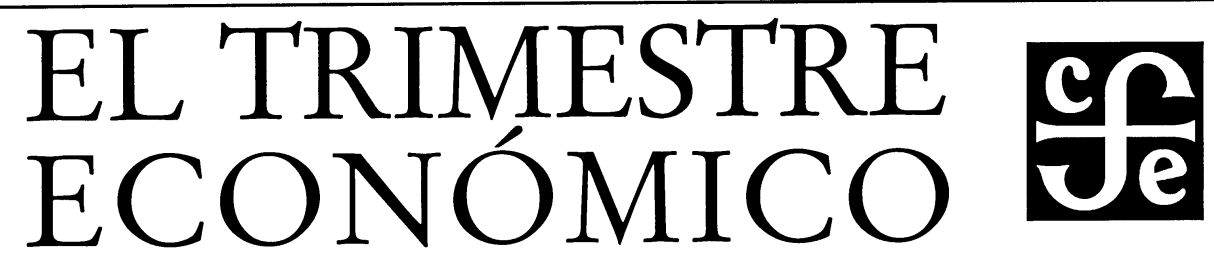

COMITÉ DICTAMINADOR: Enrique Casares Gil (UAM-A), Gonzalo Castañeda (Colmex), Sara Castellanos (Secretaría de Economía), Gerardo Esquivel (Colmex), Lorenza Martínez (ITAM), Juan Carlos Moreno Brid (CEPAL), Antonio Noriega Muro (Universidad de Guanajuato), Martín Puchet Anyul (UNAM), Graciela Teruel (UIA). CONSEJO EDITORIAL: Edmar L. Bacha, Gerardo Bueno, Enrique Cárdenas, Arturo Fernández, Ricardo Ffrench-Davis, Enrique Florescano, Roberto Frenkel, Kevin B. Grier, Ricardo Hausmann, Alejandro Hernández, Albert O. Hirschman, Hugo A. Hopenhayn, David Ibarra, Felipe Larraín, Francisco Lopes, Guillermo Maldonado, Rodolfo Manuelli, José A. Ocampo, Joseph Ramos, Luis Ángel Rojo Duque, Gert Rosenthal, Francisco Sagasti, Jaime José Serra, Jesús Silva Herzog Flores, Osvaldo Sunkel, Carlos Tello, Sweder van Winjberger.

Director: Fausto Hernández Trillo

Secretario de redacción: Guillermo Escalante A.

Asistente editorial: Karla López

Vol. LXXV (4)

México, octubre-diciembre de 2008

Núm. 300

\section{PERSPECTIVA ECONÓMICA}

Enrique Cárdenas S.

El mito del gasto público deficitario en México (1934-1956)

\section{ARTÍCULOS}

Luis F. López-Calva, Álvaro Meléndez

Martinez, Ericka G. Rascón Ramírez, Lourdes

Rodriguez-Chamussy y Székely Pardo

Patricio Meller y David Rappoport

Dante Contreras, Ryan Cooper y Christopher Neilson

Patricio Jaramillo G. y Jorge Selaive C.

Gustavo Genoni y Jorge Niño

Salvador Marin, Juan Gómez y Juan Cándido Gómez

Luis Ferruz, José Luis Sarto y Luis Vicente
El ingreso de los hogares en el mapa de México

¿Son siempre las universidades la mejor opción para un título profesional? Evidencia chilena

Crecimiento pro pobre en Chile

Especuladores en el mercado del cobre

Manipulación de resultados en la Banca chilena por medio de la estimación de incobrables

Eficiencia técnica en el sistema bancario español. Dimensión y rentabilidad

Convergencia estratégica en la industria española de fondos de inversión

EL TRIMESTRE ECONÓMICO aparece en los meses de enero, abril, julio y octubre. La suscripción en México cuesta $\$ 375.00$. Número suelto $\$ 120.00$.

$$
\text { Precios para otros países (dólares) }
$$

Centroamérica y el Caribe

$$
\text { Suscripciones }
$$

Sudamérica y España

135.00

Número suelto

35.00

38.00

Fondo de Cultura Económica, Carretera Picacho Ajusco 227, Col. Bosques del Pedregal, 14738 México, D.F. Suscripciones y anuncios: Tel. (52) (55) 5227-4671 Fax (52) (55) 5227-4640 señora Irma Barrón Correo electrónico: trimestre@fondodeculturaeconomica.com

Página del Fondo de Cultura Económica en Internet: http://www.fondodeculturaeconomica.com 


\section{Alum: \\ HISTORIA INDUSTRIAL ECONOMÍA Y EMPRESA}

J. MORENO, Tecno-

logía, empresa y

mercado en la fabri-

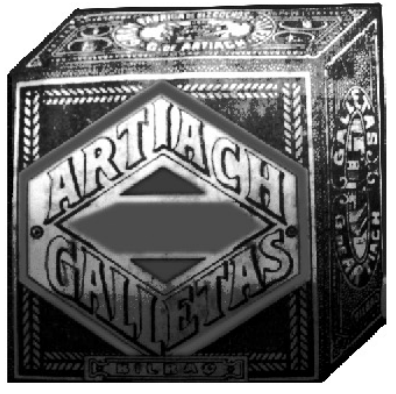

1975. J. L. RAMOS

GOROSTIZA, Re-

formismo social y

cación española de galletas. • “ciudad-jardín” en España.

P. PASCUAL, La industria del • J.L. LOUBET, El automóvil

cobre en España. I. De 1900 a • en Francia y la globalización

N O T A S D E I N V E S T I G A C I Ó N • R E C E N S I O N E S 


\section{Historia Agraria revista de agricultura e historia rural}

\section{5}

Estudios

Del diezmo islámico al diezmo real.

La renta agraria en Toledo (ss. XI-XV)

JOSÊ-DAMIÁN GONZÁLEZ-ARCE

Mercado y precios. El Almudí de Lérida, 1700-1833

ENRIC VICEDO-RIUS

El empresariado vitivinícola de la provincia

de Mendoza (Argentina) a principios del siglo XX

PATRICIA BARRIO

El fracaso del lobby viticultor en España

frente al objetivo industrializador del Estado, 1920-1936

EVA FERNÁNDEZ

La obra agraria de Joaquín Costa.

Aportaciones bibliográficas

ELOY FERNÁNDEZ CLEMENTE

Crítica de libros

Suscripciones:

SOCIEDAD ESPAÑOLA

\section{DE HISTORIA AGRARIA (SEHA)}

Secretaría del Seminario

de Historia Agraria Centre

de Recerca d'Història Rural (ILCC)

Facultat de Lletres. Universitat de Girona

Plaça Ferrater Mora, 1

17071 Girona

Tel.: +34972 418945 - Fax: +34972418230

e-mail: rosa.congost@udg.edu

www.seha.info

\section{Envio de materiales:}

\section{REVISTA HISTORIA AGRARIA}

Facultad de Economía y Empresa

Univ. de Murcia 30100 Espinardo (Murcia)

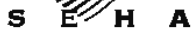

SOCIEDAD ESPAÑOLA

DE HISTORIA A G R A I A
Tel.: +34 968367962 - Fax: +34968363745 e-mail: rha@um.es

\section{Intercambio:}

SERV. DE INTERCAMBIO CIENTÍFICO

Universidad de Murcia Tel.: +34968 363692 - e-mail: mdem@um.es 


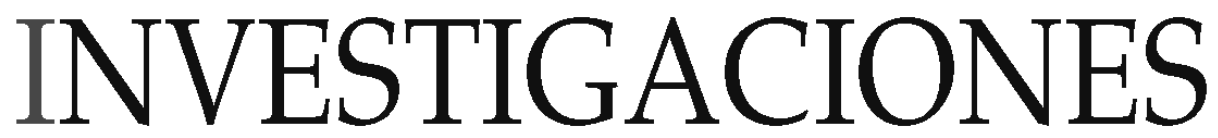

$2008 \cdot$ OTOÑO NÚMERO 12

de HISTORIA ECONÓMICA

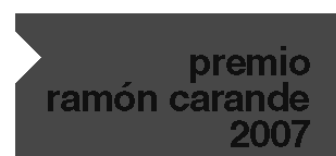

EVA FERNÁNDEZ GARCÍA

Las políticas redistributivas de la España no democrática: del objetivo industrializador al sostenimiento de los ingresos de los agricultores (1950-1975)

\section{artículos}

PERE PASCUAL DOMĖNECH y CARLES SUDRIÀ TRIAY Industrialización, desarrollo financiero y oferta monetaria en Barcelona a mediados del siglo XIX

MARC PRAT SABARTÉS

Las estructuras comerciales de la industria algodonera catalana: el triunfo de los viajantes en el último tercio del siglo XIX

\section{ANDREA LLUCH}

Las agencias de informes crediticios en la Argentina: Una aproximación al funcionamiento de los mecanismos informativos en el mercado crediticio (1892-c. 1935)

PEDRO PABLO ORTÚÑ́EZ GOICOLEA

Cambio politico, instituciones y empresas ferroviarias en España (1918-1936)

JOSÉ ANTONIO ALONSO RODRÍGUEZ Contra la desmemoria. Desventuras de la Teoría del Desarrollo 


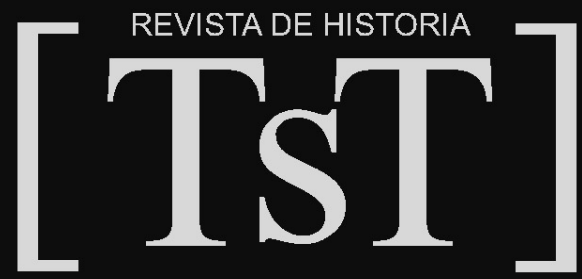

Transportes, Servicios y Telecomunicaciones

$N^{0} 14$ / junio de 2008 / 17 euros

Fundación de los Ferrocarriles Españoles
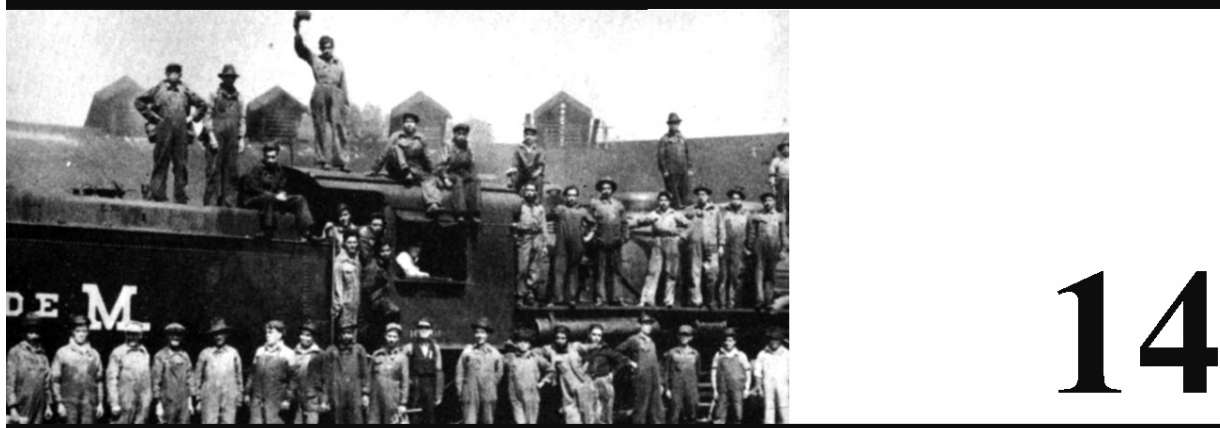

CON ARTÍCULOS DE

\section{Dossier Arturo Grunstein Dickter}

Perspectivas generales sobre el problema laboral de los Ferrocarriles Nacionales de México en la posrevolución, 1920-1935

Colin M. Lewis

Capital, tecnología y nacionalismo: economía politica de los tranvías urbanos en Anérica Latina, 1850-1940

\section{Timo Myllyntaus}

Foreign investments in Finnish electricity supply utilities, 1884-1936

Ana Cardoso de Matos y Álvaro Ferreira da Silva

Foreign capital and problems of agency: the Companhias Reunidas de Gas e Electricidade in Lisbon, 1890-1920

Patrimonio Histórico Ana María Mojarro Bayo

Los Archivos Portuarios españoles y su patrimonio documental 